Acta Technologica Agriculturae 2

Nitra, Slovaca Universitas Agriculturae Nitriae, 2019, pp. 38-42

\title{
AN ASSESSMENT OF ANAEROBIC THERMOPHILIC CO-DIGESTION OF DAIRY CATTLE MANURE AND SEPARATED TOMATO GREENHOUSE WASTE IN LAB-SCALE REACTORS
}

\author{
Đurđica KOVAČIĆ* , Davor KRALIK, Daria JOVIČIĆ, Robert SPAJIĆ \\ J. J. Strossmayer University of Osijek, Osijek, Croatia
}

\begin{abstract}
Anaerobic co-digestion of dairy cow manure (DCM) and separated tomato greenhouse waste (tomato stalks and leaves (TSL) and rotten and damaged tomato fruits - TF) was conducted under batch thermophilic conditions $\left(T=55^{\circ} \mathrm{C}\right)$ for period of 45 days. Concentrations of substrates (tomato waste) were 5 and 10\% (w/v). Each substrate, as well as experimental mixtures, was analysed in order to specify the content of $\mathrm{pH}$, total solids (TS), volatile solids (VS), total extractable nitrogen (TN) and total organic carbon (TOC). Biogas yield and composition, as well as cumulative biogas curves, were reported. In comparison to DCM monodigestion (329.5 $\left.\mathrm{cm}^{3} \cdot \mathrm{g}^{-1} \mathrm{VS}\right)$, biogas yield was significantly improved in experiment C (365.1 $\left.\mathrm{cm}^{3} \cdot \mathrm{g}^{-1} \mathrm{VS}\right)$ (with $5 \%$ (w/v) TF added), whereas methane yield did not show any significant difference. Experiment D (with 10\% (w/v) TSL added) resulted in significantly lower biogas and methane yields in contrast to the rest of experiments performed. Average methane content in all analysed experimental samples ranged from 65 to $69 \%$. It is evident from the results that biogas production can be improved by addition of separated tomato greenhouse waste to DCM process and issue of organic waste disposal could be effectively solved.
\end{abstract}

Keywords: anaerobic co-digestion; biogas; dairy cow manure; methane; tomato greenhouse waste

In recent years, increasing attention has been paid to the proper care and management of organic agricultural waste and residuals. Scientists from all over the world are striving to develop technologies of waste management that would be simple to introduce to everyday life and would also be economical for use, as well as would be safe for both human health and environment. Biogas production utilizing waste treatment and recycling or composting can reduce pollution and disease transfer (Chongrak, 2007). Biogas production by means of anaerobic digestion provides essential benefits in contrast to other forms of bioenergy production, since it is considered a complete waste-to-energy transformation (Adekunle and Okolie, 2015; Cavinato et al., 2010). Due to its beneficial properties, various types of manure are commonly utilized as the base substrate in anaerobic digestion process (Nghiem et al., 2017, Kažímírová et al., 2018). However, digesting manure alone may not represent the most efficient way to produce biogas. One of the approaches for improving the manure digestion is to increase the biogas production rate by co-digesting it with other kinds of waste to achieve synergistic effects: balancing the $\mathrm{C} / \mathrm{N}$ ratio, macro and micronutrients, $\mathrm{pH}$, inhibitors/toxic compounds and total solids (TS) or volatile solids (VS) content (Li et al., 2011; Wang et al., 2014; Kovačić et al., 2017). There have been conducted numerous studies dealing with co-digestion of various organic wastes with dairy cow manure (DCM), e.g. food wastes (Li et al., 2010; Luo and Angelidaki, 2013; Zarkadas et al., 2015), harvest residues (Wang et al., 2012; Yue et al., 2013; Li et al., 2014; Kovačić et al., 2018), wastewaters and effluents (Ogejo and Li, 2010; O-Thong et al., 2012; Siddiq et al., 2014). However, there is scarcity of information on anaerobic co-digestion of separated tomato greenhouse waste with different types of manure and its potential for utilization in biogas production. Li et al. (2016) conducted solid-state anaerobic co-digestion of tomato residues with dairy manure and corn stover (11 different substrate ratios) under mesophilic regime during 45 days. Results showed improved methane yield $\left(415.4 \mathrm{~cm}^{3} \cdot \mathrm{g}^{-1} \mathrm{VS}_{\text {feed }}\right)$ after co-digestion at ratio of $33 \%$ corn stover, $54 \%$ dairy manure and $13 \%$ tomato residues (wet base), with a reference to 0.5-10.2-fold higher yields than that of individual feedstock. Production inhibition of volatile fatty acids took place at content of tomato residues exceeding 40\%. Mishra and Tenneti (2015) anaerobically co-digested tomato waste and cow dung as substrate and inoculum, respectively, in batch mesophilic and semi-continuous reactors at various hydraulic retention times. Maximum specific biogas production of $170 \mathrm{~cm}^{3} \cdot \mathrm{g}^{-1}$ VS per day was observed during the second week of continuous operation. Saev et al. (2009) performed anaerobic co-digestion of tomato waste and cattle manure in semi-continuous mode at mesophilic conditions. The average biogas yield was $220 \mathrm{~cm}^{3} \cdot \mathrm{g}^{-1} \mathrm{VS}$, while maximal methane production in total was achieved when the ratio of cattle manure/tomato waste was $80: 20$ and organic loading rate was $2.9 \mathrm{~kg} \mathrm{VS} \mathrm{m}^{-3} \cdot \mathrm{d}^{-1}$. Saghouri et al. (2018) conducted anaerobic co-digestion of waste from tomato processing in lab-scale batch mesophilic reactors with continuous mixing lasting 48 days. Slurry of digested

Contact address: Đurđica Kovačić, J. J. Strossmayer University of Osijek, Faculty of Agrobiotechnical Sciences Osijek, Vladimira Preloga 1, HR - 31000 Osijek, Croatia, e-mail: durda7@gmail.com 
cattle manure was used as inoculum. The highest produced biogas yield was $140 \mathrm{~cm}^{3} \cdot \mathrm{g}^{-1}$ VS and highest methane content was $60.5 \%$ in produced biogas.

Addition of vegetable waste to DCM can be a suitable option for improving the process of anaerobic digestion. Manure usually provides good buffering capacity and contains all nutrients required by the anaerobic bacteria, especially nitrogen (Nghiem et al., 2017; Wang et al., 2014; Zhang et al., 2017).Vegetable waste has high moisture content (75-90\%) and is highly biodegradable, which encourages the rapid production of volatile fatty acids. These acids lead to a rapid $\mathrm{pH}$ drop, which may inhibit methanogenic activity. Moreover, vegetable waste is low in nitrogen and phosphorus, which may result in low methane yield when monodigested. Therefore, mixing it with other wastes, such as manure, which has higher nitrogen content, is preferable. In such manner, system acidification can be avoided (Tarekegn and Abebe, 2017; Siripong and Dulyakasem, 2012).

Aim of this work was to investigate the anaerobic co-digestion potential of separated tomato greenhouse waste residues with DCM under batch thermophilic regime, in which tomato greenhouse waste was added to DCM in two different proportions.

\section{Material and methods}

\section{Substrates}

Industrial waste in the production of tomatoes (stalks, leaves, rotten and damaged tomato fruits) used in this study was collected from the greenhouse "Magadenovac" (Slavonia and Baranja County, Croatia); it was stored in a freezer at $-20{ }^{\circ} \mathrm{C}$ for later use. Tomato samples were defrosted at $4{ }^{\circ} \mathrm{C}$ for $24 \mathrm{~h}$, oven dried at $60^{\circ} \mathrm{C}$ for $24 \mathrm{~h}$, pruned into pieces with length of $3-5 \mathrm{~cm}$ and finally ground and homogenized in a kitchen blender. DCM was obtained from local dairy farm Topolik (Slavonia and Baranja County, Croatia). Fresh manure was obtained in $15 \mathrm{dm}^{3}$ plastic pails. These were delivered to the laboratory just before the commencement of experiment for the purposes of inoculum.

\section{Analytical methods}

Each substrate and inoculum were analysed for $\mathrm{pH}, \mathrm{TS}, \mathrm{VS}$, TOC and TN, which were measured in accordance with the standard methods (APHA, 1998). The $\mathrm{pH}$ was measured using a portable $\mathrm{pH}$ meter and combination glass electrode (Mettler Toledo Five Easy, Switzerland) at room temperature. The $\mathrm{pH}$ of ground tomato substrates was specified from suspension obtained by weighing $1 \mathrm{~g}$ of substrate. Subsequently, $20 \mathrm{~cm}^{3}$ of distilled water was added to it. Final $\mathrm{pH}$ results were shown after $30 \mathrm{~min}$. TS content was determined when weight showed no further changes during drying process at $105{ }^{\circ} \mathrm{C}$ in the laboratory oven (Memmert UFE 600, Germany). Considering the VS content, it was determined by means of complete combustion in a muffle furnace that lasted for $4 \mathrm{~h}$ at $550{ }^{\circ} \mathrm{C}$. Kjeldahl method (Büchi digestion unit K-437, Büchi distillation unit B-324, Switzerland) was utilized for determination of TN content. TOC content was specified in accordance with an international standardization operation method (ISO
14235, 1998) (UV-VIS spectrophotometer Cary 50, Varian, Australia).

Sampling and biogas composition analyses were conducted on daily basis until the methanogenesis commencement. Subsequently, sampling and biogas composition analyses were performed on every fourth day. A modified method (HRN ISO 6974-4:2000) using a GC (Varian 3900, USA) equipped with capillary column CP-PoraPLOT Q fused silica PLOT $25 \times 0.53 \mathrm{~mm}, d f=20 \mu \mathrm{m}$ was utilized in order to analyse the biogas composition.

\section{Lab-scale batch anaerobic co-digestion}

Ground tomato substrates were homogenized with DCM prior to anaerobic batch co-digestion. Experiments were carried out under thermophilic conditions $\left(T=55^{\circ} \mathrm{C}\right)$ for period of $t=45$ days in apparatus described in our previous research (Kovačić et al., 2018).

Reaction mixture was of total volume of $500 \mathrm{~cm}^{3}$. The substrates concentrations were 5 and $10 \%(w / v)$. Each experiment was triplicated. Content of each reactor was subtly mixed manually five times a day in order to ensure homogeneity. Furthermore, single DCM was digested as well in order to provide control and comparison sample. The experimental design is shown in Table 1.

Table 1 Experimental design

\begin{tabular}{|l||c|c|}
\hline Experiment & $\begin{array}{c}\text { Composition of experimental } \\
\text { sample }\end{array}$ & $\begin{array}{c}\text { Mixture } \\
\text { symbol }\end{array}$ \\
\hline \hline Inoculum & DCM & A \\
\hline $\mathbf{1}$ & DCM + TSL 5\% (w/v) & B \\
\hline $\mathbf{2}$ & DCM + TF 5\% (w/v) & C \\
\hline $\mathbf{3}$ & DCM + TSL 10\% (w/v) & D \\
\hline $\mathbf{4}$ & DCM + TF 10\% (w/v) & E \\
\hline & $\begin{array}{l}\text { DCM - dairy cow manure, TF - tomato fruits, TSL - } \\
\text { tomato stalks and leaves }\end{array}$
\end{tabular}

\section{Statistical analysis}

Statistical analysis of biogas and methane yields was done according to analysis of variance (ANOVA) by means of SAS software for Windows (SAS Institute Inc., Cary, NC, USA). In case of occurrence of statistically significant differences $(p<0.05)$, the means were subsequently separated by means of Fisher's multiple range test. All results provided are mean values.

\section{Results and discussion}

In this research, addition of separated tomato greenhouse waste (TSL and rotten and damaged TF) to DCM was evaluated in order to conduct the process of anaerobic co-digestion. As far as it is possible to claim, this is the first attempt to perform batch anaerobic co-digestion of separated tomato greenhouse waste and DCM under thermophilic regime.

Main substrate properties are shown in Table 2.

Addition of acidic tomato greenhouse waste slightly lowered $\mathrm{pH}$ value of experimental mixtures $\mathrm{pH}$ 
Table 2 Main properties of raw substrates and inoculum

\begin{tabular}{|c|c|c|c|c|c|c|c|}
\hline & pH & TS $(\%)^{*}$ & VS (\%)** & Ash $(\%)^{* *}$ & TN (\%)** & TOC (\%)** & $\mathrm{C} / \mathrm{N}$ \\
\hline \multicolumn{8}{|c|}{ Raw substrates and inoculum } \\
\hline DCM & $7.03 \pm 0.01$ & $6.58 \pm 0.07$ & $84.51 \pm 0.55$ & 15.49 & $4.56 \pm 0.02$ & $37.78 \pm 0.27$ & 8.3 \\
\hline TSL & $5.12 \pm 0.03$ & $12.52 \pm 0.25$ & $86.60 \pm 0.20$ & 13.40 & $2.27 \pm 0.04$ & $41.47 \pm 0.34$ & 18.3 \\
\hline TF & $4.03 \pm 0.03$ & $7.63 \pm 0.23$ & $93.21 \pm 0.14$ & 6.79 & $3.46 \pm 0.03$ & $44.30 \pm 0.25$ & 12.8 \\
\hline \multicolumn{8}{|c|}{ Experimental mixtures } \\
\hline B & $6.75 \pm 0.00$ & $7.00 \pm 0.07$ & $84.02 \pm 0.66$ & 15.31 & $3.84 \pm 0.34$ & $38.24 \pm 0.80$ & 10.0 \\
\hline C & $6.70 \pm 0.01$ & $6.56 \pm 0.04$ & $83.63 \pm 0.40$ & 13.87 & $3.92 \pm 0.21$ & $41.67 \pm 0.23$ & 10.6 \\
\hline D & $6.61 \pm 0.07$ & $8.50 \pm 1.12$ & $86.58 \pm 0.24$ & 13.46 & $3.57 \pm 0.03$ & $39.14 \pm 0.66$ & 11.0 \\
\hline $\mathbf{E}$ & $6.53 \pm 0.04$ & $6.80 \pm 0.04$ & $86.78 \pm 0.18$ & 12.22 & $3.74 \pm 0.17$ & $42.06 \pm 0.54$ & 11.2 \\
\hline
\end{tabular}

6.5-7.7) making the mixtures still sufficiently amenable to methanogenic bacteria and thus allowing them to function properly and attain maximal biogas yield (Tarekegn and Abebe, 2017; Khalid et al., 2011). C/N ratio is another important factor that affects process of biogas production. Siddiqui et al. (2011) reported ideal C/N ratio within the range of 9 to 30 . $\mathrm{C} / \mathrm{N}$ ratio in DCM was quite low (approx. 8 ). On the contrary, it was higher (approx. 18 and 12, respectively) in tomato green parts and fruits. Thereby, by addition of tomato residues to manure, there was an increase in $\mathrm{C} / \mathrm{N}$ ratio in all prepared experimental mixtures (to approx. 10-11), resulting in more favourable media for methanogens.

Daily biogas production curves are presented in Fig. 1. General variation is evident between samples containing
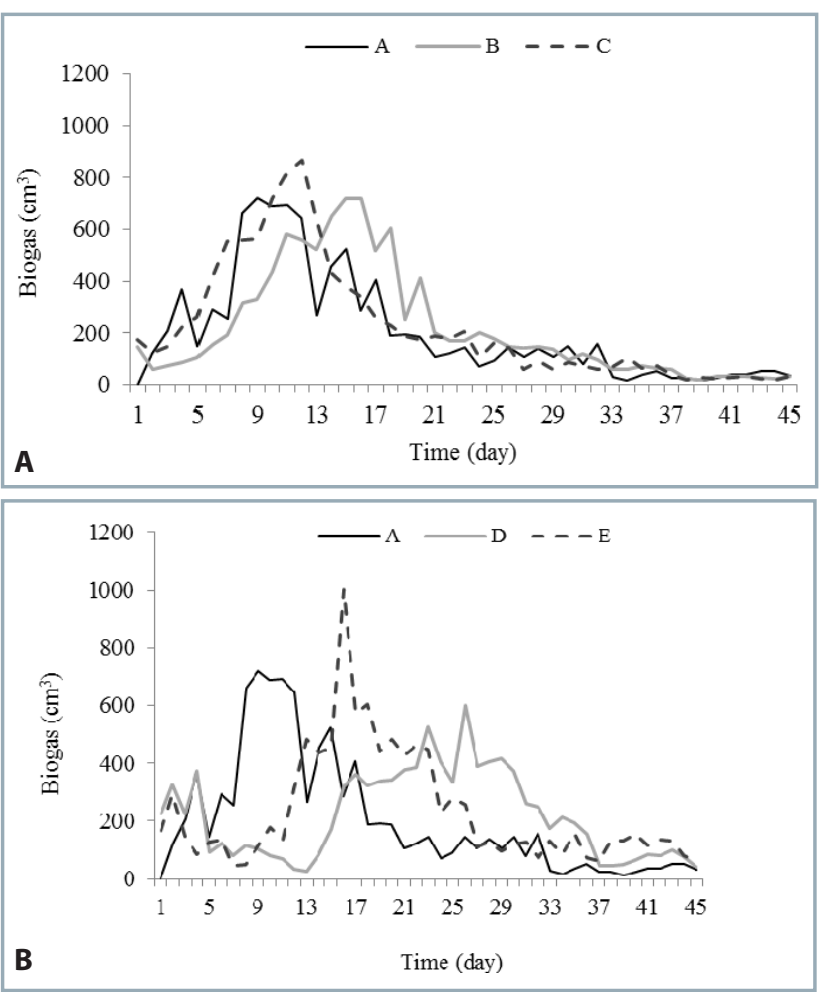

Fig. 1 Daily biogas production during anaerobic co-digestion of DCM and tomato greenhouse waste residuals added: A) $5 \%(\mathrm{w} / \mathrm{v})$ added; B) $10 \%(\mathrm{w} / \mathrm{v})$ added
5 and $10 \%(w / v)$ tomato residues. Methanogenesis progress was quite similar in experiments containing $5 \%(\mathrm{w} / \mathrm{v})$ tomato residues and experiment containing pure manure. Several peak values were recorded for all three experiments during observed period (experiments A, B and C).

The highest biogas production in reactor containing DCM started on the $8^{\text {th }}$ day of the process and lasted for 8 days. However, in experiments containing tomato residues, beginning of highest biogas production varied between the samples. The highest biogas production started on the $11^{\text {th }}$ and $7^{\text {th }}$ day of the process and dynamic phase of biogas production lasted for 8 and 7 days in experiment B and C, respectively.

However, addition of $10 \%(\mathrm{w} / \mathrm{v})$ tomato residues to manure resulted in more equable process without multiple peak values and beginning of higher biogas production started quite later on - on the $23^{\text {rd }}$ and $13^{\text {th }}$ day in experiments $D$ and $E$, respectively. That dynamic phase of biogas production lasted for 4 and 6 days, respectively, implying that biogas production was more balanced throughout the process in contrast to experiments containing $5 \%(\mathrm{w} / \mathrm{v})$ tomato residues added.

After anaerobic co-digestion of DCM and tomato greenhouse waste residuals, average cumulative biogas yields (Fig. 2) were specified.

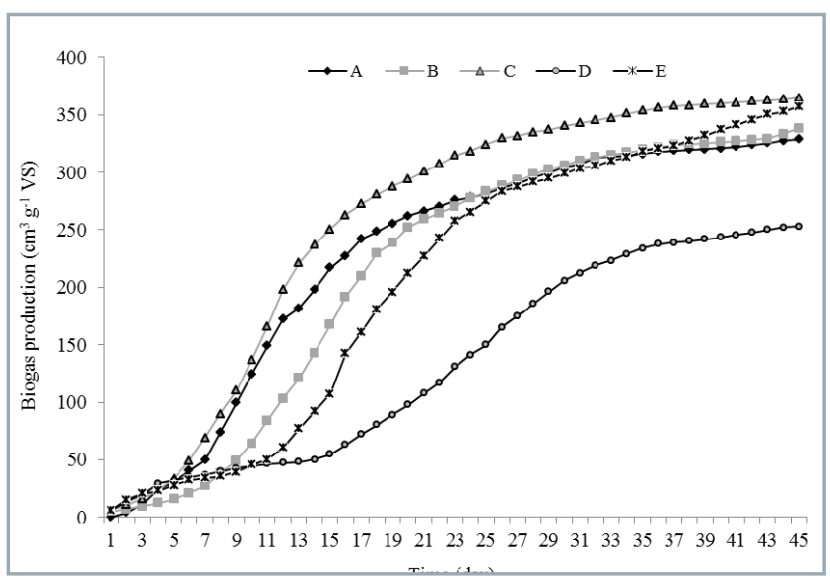

Fig. 2 Average cumulative biogas yields after anaerobic co-digestion of DCM and greenhouse waste residuals 


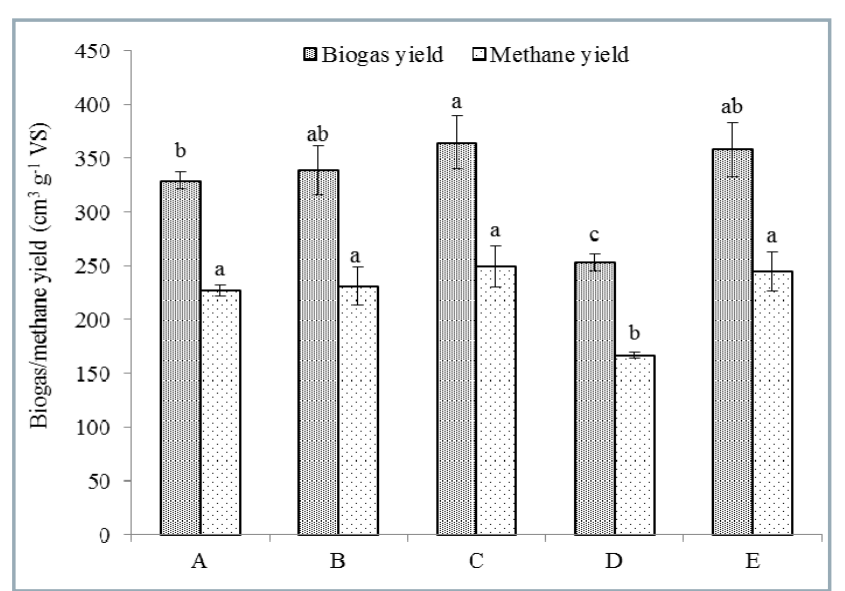

Fig. 3 Biogas and methane yields obtained from co-digested experimental samples; standard deviation is indicated by error bars $(n=3)$

Average cumulative biogas yields obtained in experiments $B, C$ and $E$ were higher in contrast to $D C M$ monodigestion by $2.7,9.8$ and $7.8 \%$, respectively, whereas in experiment $C$, the highest biogas production was specified during entire process. Moreover, in terms of biogas yield, statistically significant difference was shown solely in experiment $\mathrm{C}$ in comparison to all other experiments (Fig. 3 ).

Furthermore, comparing it to the rest of experiments conducted, experiment $D$ showed quite lower biogas production, which can be probably associated to overly high concentration of hardly/slowly degradable carbohydrates and fibres in TSL. Moreover, experiment D showed significantly lower biogas yield as well as and methane yield in contrast to all other experiments (Fig. 3).

Biogas and methane yields obtained from each experimental mixture are provided in Fig. 4. Biogas and methane yields achieved after anaerobic DCM monodigestion (experiment A) were 329.5 and $227.2 \mathrm{~cm}^{3} \cdot \mathrm{g}^{-1}$ VS, respectively. Statistically significant ( $p>0.05$ ) improvement in biogas yield was gained in experiment $C\left(365.1 \mathrm{~cm}^{3} \cdot \mathrm{g}^{-1} \mathrm{VS}\right)$ in contrast to experiment $A$. However, methane yield, which was $249.7 \mathrm{~cm}^{3} \cdot \mathrm{g}^{-1}$ VS $(9.0 \%$ higher in comparison to monodigested DCM), resulted in no significant difference. There was not observed any statistically significant difference in biogas yield increase between all other experiments and experiment A. However, all experiments showed more efficient biogas and methane yields in contrast to monodigested DCM. Experiments $B$ and E resulted in 2.8 and $2.7 \%$, and 8.1 and $4.2 \%$ higher biogas and methane yields, respectively. Experiment $D$ showed statistically significant lower biogas and methane yields ( 253.5 and $166.7 \mathrm{~cm}^{3} \cdot \mathrm{g}^{-1} \mathrm{VS}$, respectively) in contrast to the rest of other experiments conducted.

If compared to monodigested DCM, higher methane production was recorded in experimental samples containing tomato greenhouse waste residuals ( $B, C, D$, E) during almost the entire process. Methane content observed in produced biogas ranged from 65 to $69 \%$ in all experimental samples.

There is not much research in literature available regarding co-digestion of tomatogreenhouse wasteand DCM. Saghouriet al. (2018) anaerobically digested waste from tomato processing
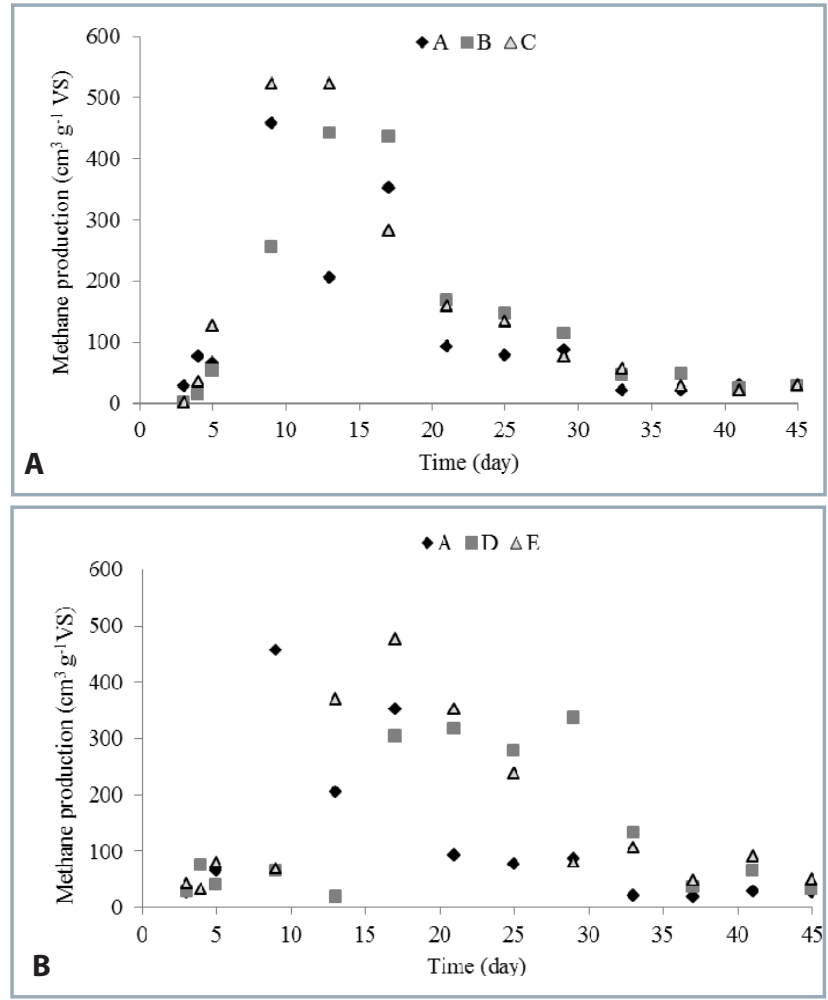

Fig. 4 Biogas and methane content produced by means of anaerobic co-digestion of dairy manure and tomato greenhouse waste residuals: A) 5\% (w/v) added, B) 10\% $(\mathrm{w} / \mathrm{v})$ added

using the slurry of digested cow dung as inoculum. The research was conducted in single-stage batch digester with continuous mixing under mesophilic conditions for 45 days and resulting in $140 \mathrm{~cm}^{3} \cdot \mathrm{g}^{-1} \mathrm{VS}$ (with $60 \%$ methane content), which is quite low in comparison to biogas yields obtained in this research after anaerobic co-digestion experiments. Furthermore, Sarada and Joseph (1996) conducted a study in order to compare single and two stage processes for methane production from waste from tomato processing under mesophilic conditions. Authors examined the factors having impact on the total biogas yield, such as loading rate, hydraulic retention time and temperature during the digestion process. The highest biogas yield reported $\left(800 \mathrm{~cm}^{3} \cdot \mathrm{g}^{-1} \mathrm{VS}, 65 \%\right.$ methane content) was gained on the $24^{\text {th }}$ day of hydraulic retention time, at $4.5 \mathrm{~kg} \cdot \mathrm{m}^{-3}$ loading rate and temperature of $35^{\circ} \mathrm{C}$, resulting in $40-50 \%$ increment in both rate and yield of methane, as well as total biogas production in contrast to the single stage process under similar regime. Saev et al. (2009) examined anaerobic co-digestion of different mixtures of waste from tomato processing and cattle manure in semi-continuous lab-scale reactor under mesophilic regime and at hydraulic retention time of 20 days. The highest biogas yield $\left(400 \mathrm{~cm}^{3} \cdot \mathrm{g}^{-1} \mathrm{VS}\right)$ and methane yield $\left(220 \mathrm{~cm}^{3} \cdot \mathrm{g}^{-1} \mathrm{VS}\right)$ was achieved after co-digestion of mixing ratio $80: 20$ (cattle manure : diluted tomato waste) and 20:80 (cattle manure : tomato waste), respectively.

\section{Conclusion}

Addition of separated tomato greenhouse waste (TSL and rotten and damaged TF) to DCM was studied in order to assess the effect of anaerobic co-digestion efficiency. Two 
different proportions $(5 \%$ and $10 \%(\mathrm{w} / \mathrm{v}))$ of tomato waste residues were added to DCM with aim to enhance biogas production process.

Anaerobic co-digestion of tomato greenhouse waste and DCM (experiments $B, C$ and $E$ ) resulted in more efficient process in comparison to DCM monodigestion. Experiment $C$ resulted in significantly improved biogas yield (9.8\%) in comparison to DCM monodigestion. However, methane yield was not statistically significantly improved - there was observed $9.0 \%$ increment in methane yield.

Experiment B and E resulted in 2.8 and $2.7 \%$, and 8.1 and 4.2\% higher biogas and methane yields, respectively.

It was solely the experiment $D$ that showed lower results in both biogas and methane yields (23.1 and 26.6\%, respectively) in contrast to DCM monodigestion.

\section{References}

ADEKUNLE, K. F. - OKOLIE, J. A. 2015. A review of biochemical process of anaerobic digestion. In Advances in Bioscience and Biotechnology, vol. 6, pp. 205-212.

AMERICAN PUBLIC HEALTH ASSOCIATION (APHA). 1998. Standard Methods for the Examination of Water and Wastewater. $20^{\text {th }}$ ed., Washington DC, USA.

CAVINATO, C. - FATONE, F. - BOLZONELLA, D. - PAVAN, P. 2010. Thermophilic anaerobic co-digestion of cattle manure with agro-wastes and energy crops: Comparison of pilot and full scale experiences. In Bioresource Technology, vol. 101, pp. 545-550.

CHONGRAK, P. 2007. Organic Waste Recycling: Technology and Management. London : IWA Publishing.

ISO 14235. 1998. Soil quality - Determination of organic carbon by sulfochromic oxidation.

KAŽíMÍROVÁ, V. - GADUŠ, J. - GIERTL,T. 2018. Verification of suitability of substrate composition for production and quality of biogas. In Acta Technologica Agriculturae, vol. 21, no. 3, pp. 115-118.

KHALID, A. - ARSHAD, M. - ANJUM, M. - MAHMOOD, T. - DAWSON, L. 2011. The anaerobic digestion of solid organic waste. In Waste Management, vol. 31, no. 8, pp. 1737-1744.

KOVAČIĆ, Đ. - KRALIK, D. - JOVIČIĆ, D. - RUPČIĆ, S. - POPOVIĆ, B. TIŠMA, M. 2018. Thermal pretreatment of harvest residues and their use in anaerobic co-digestion with dairy cow manure. In Applied Biochemistry and Biotechnology, vol. 184, no. 2, pp. 471-483. KOVAČIĆ, Đ. - KRALIK, D. - RUPČIĆ, S. - JOVIČIĆ, D. - SPAJIĆ, R. - TIŠMA, M. 2017. Soybean straw, corn stover and sunflower stalk as possible substrates for biogas production in Croatia: A review. In Chemical and Biochemical Engineering Quarterly, vol. 31, no. 3, pp. 187-198.

LI, J. - WEI, L. - DUAN, Q. - HU, G. - ZHANG, G. 2014. Semi-continuous anaerobic co-digestion of dairy manure with three crop residues for biogas production. In Bioresource Technology, vol. 156, pp. 307-313. LI, R. - CHEN, S. - LI, X. 2010. Biogas production from anaerobic codigestion of food waste with dairy manure in a two-phase digestion system. In Applied Biochemistry and Biotechnology, vol. 160, no. 2, pp. 643-654.

LI, Y. - LI, Y. - ZHANG, D. - LI, G. - LU, J. - LI, S. 2016. Solid state anaerobic co-digestion of tomato residues with dairy manure and corn stover for biogas production. In Bioresource Technology, vol. 217, pp. 50-55.

LI, Y. - PARK, S. Y. - ZHU, J. 2011. Solid-state anaerobic digestion for methane production from organic waste. In Renewable \& Sustainable Energy Reviews, vol. 15, pp. 821-826.

LUO, G. - ANGELIDAKI, I. 2013. Co-digestion of manure and whey for in situ biogas upgrading by the addition of $\mathrm{H} 2$ : process performance and microbial insights. In Applied Microbiology and Biotechnology, vol. 97, no. 3, pp. 1373-1381.
MISHRA, S. - TENNETI, S. 2015. Effect of operational parameters on biogas production using tomato waste as substrate and cow dung as inoculating medium. In International Journal of Scientific Research, vol. 4, no. 5, pp. 148-152.

NGHIEM, L. D. - HAI, F. I. - PRICE, W. E. - WICKHAM, R. - NGO, H. H GUO, W. 2017. By-products of Anaerobic Treatment: Methane and Digestate from Manures and Cosubstrates. In: Lee, D. - Jegatheesan, V. - Ngo, H. H. - Hallenbeck, P. C. - Pandey, A. editors. Current Developments in Biotechnology and Bioengineering. Amsterdam, London : Elsevier Science B. V., pp. 469 - 473.

OGEJO, J. A. - LI, L. 2010. Enhancing biomethane production from flush dairy manure with turkey processing wastewater. In Applied Energy, vol. 87, no. 10, pp. 3171-3177.

O-THONG, S. - BOE, K. - ANGELIDAKI, I. 2012. Thermophilic anaerobic co-digestion of oil palm empty fruit bunches with palm oil mill effluent for efficient biogas production. In Applied Energy, vol. 93, pp. 648-654.

SAEV, M. - KOUMANOVA, B. - SIMEONOV, I. 2009. Anaerobic co-digestion of wasted tomatoes and cattle dung for biogas production. In Journal of the University of Chemical Technology and Metallurgy, vol. 44, no. 1, pp. 55-60.

SAGHOURI, M. - MANSOORI, Y. - ROHANI, A. - KHODAPARAST, M. H. H. - SHEIKHDAVOODI, M. J. 2018. Modelling and evaluation of anaerobic digestion process of tomato processing wastes for biogas generation. In Journal of Material Cycles and Waste Management, vol. 20, pp. 561-567.

SARADA, R. - JOSEPH, R. 1996. A comparative study of single and two stage processes for methane production from tomato processing waste. In Process Biochemistry, vol. 31, no. 4, pp. 337-340.

SIDDIQ, N. I. - MUNAIM, M. S. A. - ZULARISAM, A. W. 2014. Mesophilic and thermophilic biomethane production by co-digesting pretreated petrochemical wastewater with beef and dairy cattle manure. In Journal of Industrial and Engineering Chemistry, vol. 20, no. 1, pp. 331-337.

SIDDIQUI, Z. - HORAN, N. J. - ANAMAN, K. 2011. Optimisation of C:N ratio for co-digested processed industrial food waste and sewage sludge using the BMP test. In International Journal of Chemical Reactor Engineering, vol. 9, no. 1, note S4.

SIRIPONG, C. - DULYAKASEM, S. 2012. Continuous co-digestion of agro-industrial residues. Master thesis, University of Borås, School of Engineering, Sweden.

TAREKEGN, M. M. - ABEBE, M. A. 2017. Characterization of fruit and vegetable wastes for biogas production under anaerobic condition. In International Journal of Scientific Research and Engineering Studies, vol. 5, no. 1, pp. 0001-0009.

WANG, X. - LU, X. - LI, F. - YANG, G. 2014. Effects of temperature and carbon-nitrogen $(\mathrm{C} / \mathrm{N})$ ratio on the performance of anaerobic codigestion of dairy manure, chicken manure and rice straw: Focusing on ammonia inhibition. In PloS One, vol. 9, no. 5, pp. e97265.

WANG, X. - YANG, G. - FENG, Y. - REN, G. - HAN, X. 2012. Optimizing feeding composition and carbon-nitrogen ratios for improved methane yield during anaerobic co-digestion of dairy, chicken manure and wheat straw. In Bioresource Technology, vol. 120, pp. 78-83.

YUE, Z. - CHEN, R. - YANG, F. - MACLELLAN, J. - MARSH, T. - LIU, Y. LIAO, W. 2013. Effects of dairy manure and corn stover co-digestion on anaerobic microbes and corresponding digestion performance. In Bioresource Technology, vol. 128, pp. 65-71.

ZARKADAS, I. S. - SOFIKITI, A. S. - VOUDRIAS, E. A. - PILIDIS, G. A. 2015. Thermophilic anaerobic digestion of pasteurised food wastes and dairy cattle manure in batch and large volume laboratory digesters: Focusing on mixing ratios. In Renewable Energy, vol. 80, pp. 432-440. ZHANG, J. - LOH, K. - LEE, J. - WANG, C. - DAI, Y. - TONG, Y. W. 2017. Three-stage anaerobic co-digestion of food waste and horse manure. In Scientific Reports, vol. 7, pp. 1269. 